\title{
Determination of environmental gamma radiation in Bitlis
}

\author{
Sultan Sahin $\mathrm{Bal}^{\mathrm{a}}$ and Sule Karatepe \\ Bitlis Eren University, Physics Department 13000, Bitlis, Turkey
}

\begin{abstract}
In this study; the environmental gamma radiation at the various points (16 points) in the districts of and in Bitlis, where it was located in the Turkey Eastern Anatolia region, were measured. The environmental gamma radiation measurement was made from two levels (the ground and one meter above the surface) by using portable gamma survey meter which consisted of 2"x2" scintillation detector $(\mathrm{NaI}(\mathrm{Tl}))$. The obtained data were discussed in considering the geological structure of the region and the other factors.
\end{abstract}

\section{Introduction}

There are two main contributions determining the level of exposure to natural radiation. The first of these are highenergy cosmic rays reaching to the earth's atmosphere. The other is that there are radioactive elements in the crust of the World (environment, even in the human body) [1]. The contribution of natural radiation of cosmic rays varies with altitude. As one climbs up from sea level to remain constant in certain latitude [2].

The basic levels of natural radiation varies depending on the geological and geographical features of area. Soil and rock mineralogical structure with geographical altitude affects the basic radiation levels in the region [3].

Natural radionuclides as ${ }^{238} \mathrm{U},{ }^{232} \mathrm{Th}$ and ${ }^{40} \mathrm{~K}$ in the soil causes to be radioactive of the soil. Natural radionuclides are mostly found in high concentrations in volcanic rocks (especially in granite), pegmatites and hydrothermal deposits. Water constantly interact with the soil and rocks around it. Therefore, the transfer possibility of interacting waters with them of the natural radionuclides in the soil and rocks is very high [4].

Soils contain an amount of radiation due to radioactive isotopes contained in incurred main material. Radionuclides that are naturally present in the earth's crust formation and their degradation products form the major part of the environmental radiation with spread gamma rays. $\mathrm{X}, \mathrm{y}$ and $\mathrm{z}$ as Long-lived radionuclides as ${ }^{238} \mathrm{U},{ }^{232} \mathrm{Th}$ and ${ }^{40} \mathrm{~K}$ is beginning of source of the radiation of terrestrial origin. The mass activity concentration of these natural radionuclides varies according to the type of soil and rock [5-7]. The mass activity concentration is radiation intensity corresponds to the absorbed dose in the air on $1 \mathrm{~m}$ height from the ground [5]. Thus, the measured radiation dose in the air is closely related to concentrations of radionuclides in the soil.

\footnotetext{
a Corresponding author: sahin.sultan@gmail.com
}

In this study Environmental gamma measurements was conducted in Bitlis. Bitlis was founded as the cities of the valley on that a natural passageway connects the Southeastern Anatolia to Eastern Anatolia on the borders of the up Firat and the up Murat regions of the Eastern Anatolia Region [8].

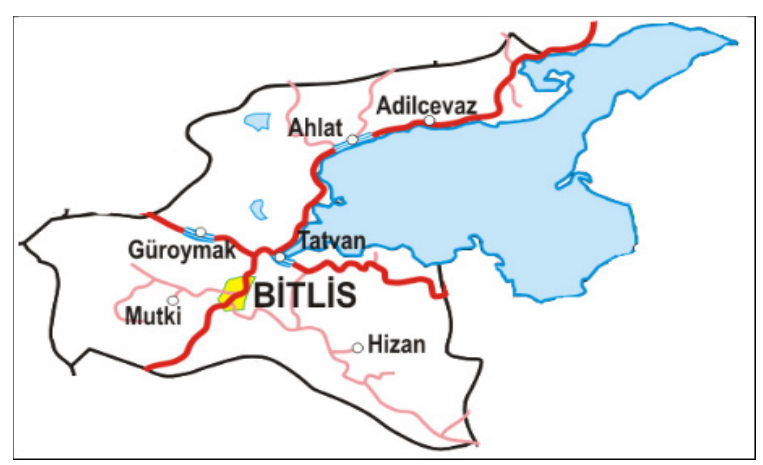

Figure 1. The map of the Bitlis and its counties

\section{Experimental}

The environmental gamma measurements in the various locations (16 points) in Bitlis was made by Dose Rate Meter that it is containing scintillation counter having to 2"x2" NaI (Tl) crystal at ground and 1m high levels [9]. The city center and its counties were easily screened because used system is portable.

\section{Results and Discussion}

Environmental gamma measurements were taken monthly periods on the ground and $1 \mathrm{~m}$ above the ground levels. Locations of 16 points on the Bitlis, where environmental gamma measurements were conducted are presented in Table 1. The measurements made $1 \mathrm{~m}$ above the soil level and the ground are presented in Table 2. 
Table 1. Location of environmental gamma measurement points.

\begin{tabular}{|c|c|c|}
\hline & Latitude (North) & Longitude (East) \\
\hline I & 38.33451 & 42.00472 \\
\hline II & 38.32286 & 42.01657 \\
\hline III & 38.33052 & 42.01483 \\
\hline IV & 38.41749 & 41.91641 \\
\hline V & 38.41745 & 41.91586 \\
\hline VI & 38.41175 & 42.11722 \\
\hline VII & 38.58592 & 42.00056 \\
\hline VIII & 38.39302 & 42.26883 \\
\hline IX & 38.39928 & 42.26320 \\
\hline X & 38.48519 & 42.32428 \\
\hline XI & 38.63133 & 42.44054 \\
\hline XII & 38.84262 & 42.82970 \\
\hline XIII & 38.78785 & 42.69599 \\
\hline XIV & 38.74583 & 42.45415 \\
\hline XV & 38.66603 & 42.30422 \\
\hline XVI & 38.63527 & 42.24807 \\
\hline
\end{tabular}

According to the data in Table 2; the measurements made in $1 \mathrm{~m}$ above the soil level and the ground from June to November are shown in Figs. 2-4.
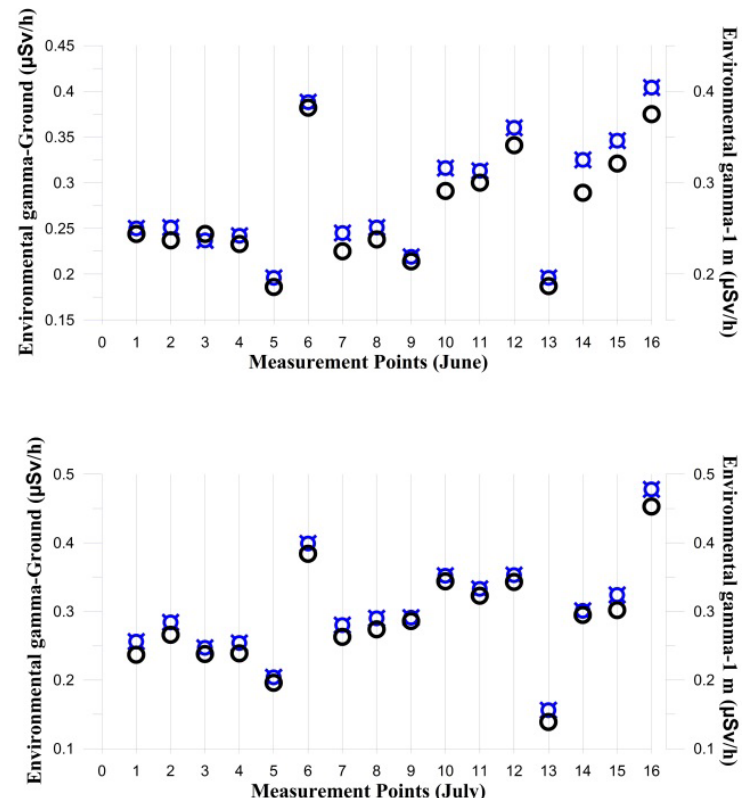

Figure 2. Environmental gamma variation at ground $(a)$ and $1 \mathrm{~m}$ level (o) on the 16 points in the June and the July.

Table 2. Formatting sections, subsections and subsubsections.

\begin{tabular}{|c|c|c|c|c|c|c|c|c|c|c|c|c|}
\hline & \multicolumn{2}{|c|}{$\begin{array}{c}\text { June } \\
(\mu \mathrm{S} v / \mathrm{h})\end{array}$} & \multicolumn{2}{|c|}{$\begin{array}{c}\text { July } \\
(\mu \mathrm{Sv} / \mathrm{h})\end{array}$} & \multicolumn{2}{|c|}{$\begin{array}{l}\text { August } \\
(\mu \mathrm{Sv} / \mathrm{h})\end{array}$} & \multicolumn{2}{|c|}{$\begin{array}{c}\text { September } \\
(\mu \mathrm{Sv} / \mathrm{h})\end{array}$} & \multicolumn{2}{|c|}{$\begin{array}{l}\text { October } \\
(\mu \mathrm{Sv} / \mathrm{h})\end{array}$} & \multicolumn{2}{|c|}{$\begin{array}{c}\text { November } \\
(\mu \mathrm{Sv} / \mathrm{h})\end{array}$} \\
\hline & Ground & $1 \mathrm{~m}$ & Ground & $1 \mathrm{~m}$ & Ground & $1 \mathrm{~m}$ & Ground & $1 \mathrm{~m}$ & Ground & $1 \mathrm{~m}$ & Ground & $1 \mathrm{~m}$ \\
\hline I & 0.250 & 0.244 & 0.256 & 0.237 & 0.308 & 0.302 & 0.250 & 0.247 & 0.230 & 0.216 & 0.205 & 0.205 \\
\hline II & 0.251 & 0.237 & 0.284 & 0.266 & 0.354 & 0.346 & 0.260 & 0.249 & 0.259 & 0.242 & 0.288 & 0.255 \\
\hline III & 0.237 & 0.244 & 0.247 & 0.238 & 0.269 & 0.258 & 0.223 & 0.219 & 0.198 & 0.186 & 0.195 & 0.193 \\
\hline IV & 0.242 & 0.233 & 0.254 & 0.239 & 0.271 & 0.271 & 0.264 & 0.262 & 0.242 & 0.225 & 0.226 & 0.207 \\
\hline $\mathrm{V}$ & 0.196 & 0.186 & 0.204 & 0.196 & 0.219 & 0.218 & 0.197 & 0.202 & 0.165 & 0.157 & 0.146 & 0.140 \\
\hline VI & 0.388 & 0.382 & 0.399 & 0.384 & 0.436 & 0.448 & 0.442 & 0.442 & 0.382 & 0.369 & 0.361 & 0.352 \\
\hline VII & 0.245 & 0.225 & 0.280 & 0.263 & 0.295 & 0.302 & 0.294 & 0.286 & 0.256 & 0.241 & 0.245 & 0.231 \\
\hline VIII & 0.251 & 0.238 & 0.290 & 0.274 & 0.311 & 0.307 & 0.268 & 0.257 & 0.265 & 0.247 & 0.239 & 0.227 \\
\hline IX & 0.219 & 0.214 & 0.291 & 0.286 & 0.332 & 0.312 & 0.313 & 0.303 & 0.292 & 0.268 & 0.268 & 0.246 \\
\hline $\mathrm{X}$ & 0.316 & 0.291 & 0.352 & 0.344 & 0.377 & 0.359 & 0.334 & 0.316 & 0.316 & 0.300 & 0.300 & 0.264 \\
\hline XI & 0.313 & 0.300 & 0.333 & 0.323 & 0.319 & 0.322 & 0.403 & 0.379 & 0.364 & 0.347 & 0.322 & 0.299 \\
\hline XII & 0.360 & 0.341 & 0.353 & 0.343 & 0.303 & 0.306 & 0.350 & 0.343 & 0.335 & 0.306 & 0.352 & 0.320 \\
\hline XIII & 0.196 & 0.187 & 0.156 & 0.139 & 0.156 & 0.151 & 0.147 & 0.143 & 0.144 & 0.128 & 0.139 & 0.132 \\
\hline XIV & 0.325 & 0.289 & 0.301 & 0.295 & 0.308 & 0.287 & 0.306 & 0.279 & 0.285 & 0.276 & 0.286 & 0.281 \\
\hline XV & 0.346 & 0.321 & 0.324 & 0.302 & 0.337 & 0.307 & 0.300 & 0.307 & 0.291 & 0.272 & 0.296 & 0.256 \\
\hline XVI & 0.404 & 0.375 & 0.478 & 0.453 & 0.527 & 0.485 & 0.435 & 0.401 & 0.416 & 0.397 & 0.380 & 0.367 \\
\hline
\end{tabular}



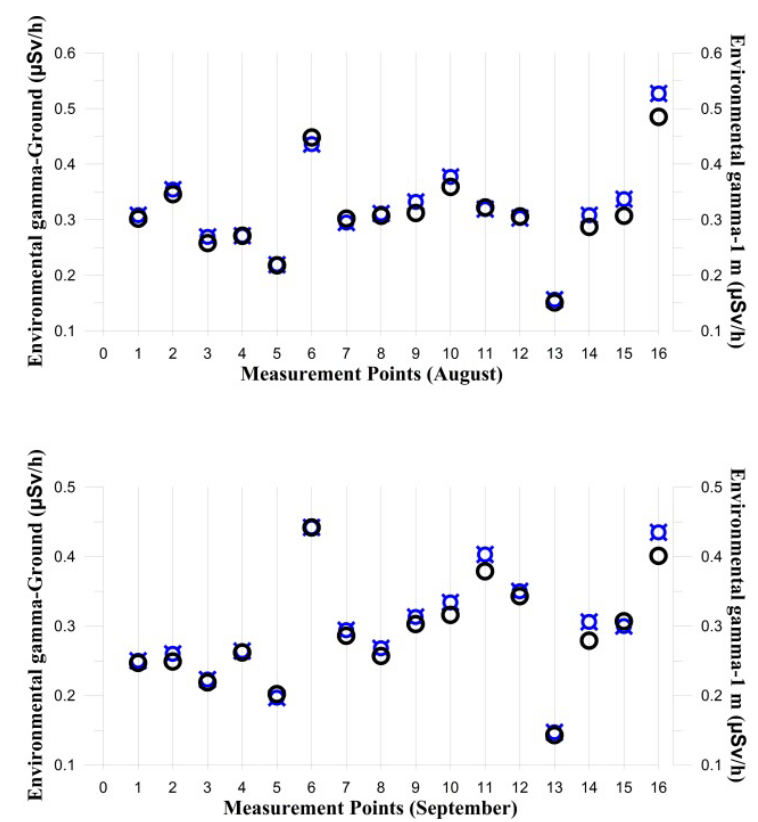

Figure 3. Environmental gamma variation at ground (a) and $1 \mathrm{~m}$ level $(\mathrm{O})$ on the 16 points in the August and the September.

It is understood from Table 2, Figs. 2-4 that the values in ground level, where gamma radiation is directly emitted from the soil, were higher than the values that were measured at $1 \mathrm{~m}$ level. It was seen that the measured environmental gamma values on XVI point measurement point in the both ground and $1 \mathrm{~m}$ level were highest and the measured environmental gamma values on XIII point were the lowest. However, it was found that $68.8 \%$ of the measured environmental gamma values on measurement points in the both ground and $1 \mathrm{~m}$ level were highest value in August and their $75 \%$ were the lowest value in November.

XVI numbered measuring point is located higher than the other measuring points. The height of this point is $2.935 \mathrm{~m}$ and XVI point is determined on a mountain that it is volcanic mountain that stood the latest activity in Turkey. To be this way of results is the expected case because the contribution to natural radiation of cosmic rays varies with height, this contribution remains constant moving up sea level on certain latitude [2], more elevation locations are exposed to more radiation than less elevation locations [10].

Cosmic radiation is consists of electromagnetic radiation or released particles at different energy and different charges. Their origins are also different. Their density decreases when it reaches the upper layers of the atmosphere to sea level [2,11]. Being the lowest of environmental gamma values measured at the measurement point XIII may be caused by less effect of electromagnetic waves (this point is further away from the other point of to residential areas) and not intense electromagnetic reflections.

\section{Conclusions}

Environmental gamma values were measured low progressed towards the winter season due to not to
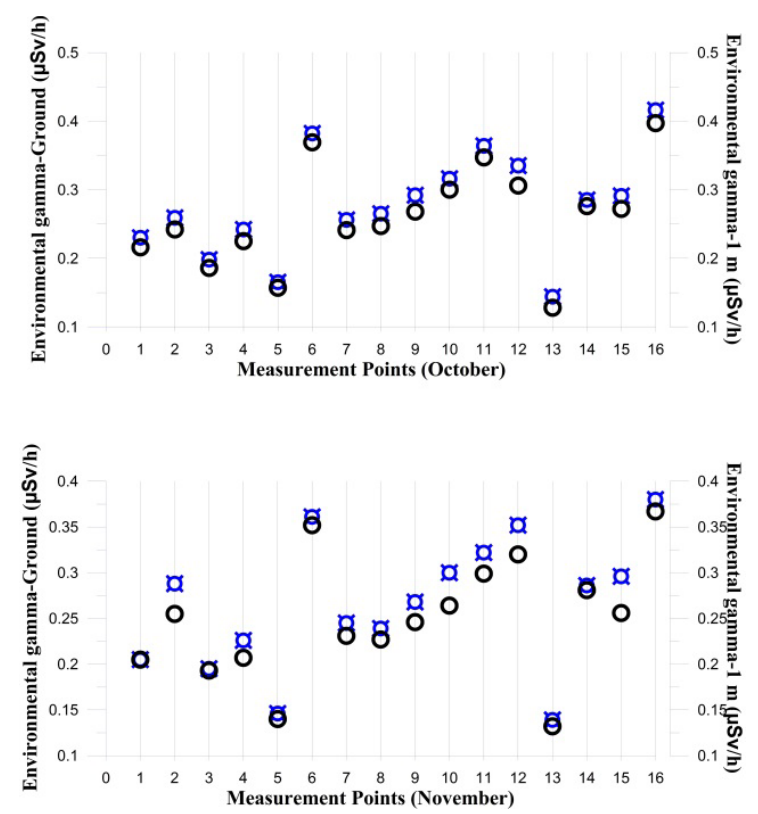

Figure 4. Environmental gamma variation at ground $(a)$ and $1 \mathrm{~m}$ level $(\circ)$ on the 16 points in the October and the November.

perpendicular and of an angle the sun's rays begin to come to earth.

Environmental gamma values measured at $1 \mathrm{~m}$ distance gives information about the concentration of radioactivity in the soil of the measurement point [7]. According to this study, the average gamma dose rate values of Bitlis and counties were measured approximately $0.28 \mu \mathrm{Svh}^{-1}$.

According to UNSCEAR (1993, 2000) report, the global average of the measured gamma dose rate ranged from 10 to $200 \mathrm{nGyh}^{-1}$. In this study, the averages of measurements taken at ground level are $291.01 \mathrm{nGyh}^{-1}$ and the averages of measurements taken at $1 \mathrm{~m}$ level are $277.68 \mathrm{nGyh}^{-1}$. When the obtained results are compared with gamma dose rate average values world; it is seen that the gamma dose rates in counties of it and Bitlis is at a level above the world average. The cause of the high levels of gamma dose rates may be geological features of the region, the absence of fault zones and the residential area of higher altitudes. The radioactivity on the fault zone is generally higher than other places, and radioactivity can be changed with the seismological aspects of activity of the fault [7].

\section{Acknowledgement}

This work was supported by BEBAP with project number is 2014.06 .

\section{References}

1. S. Kaya, S.M. Karabudak, U. Çevik, GUSTIJ, 5 (1), 24-33 (2015)

2. UNSCEAR, Sources and effects of ionizing radiation. Report to General Assembly, with Scientific Annexes (United Nations, 2000) 
3. M. Değerlier, V. Peştemalcı, Ç.Ü J. Sci. Eng., 5, 27 (2012)

4. S. Şahin Bal, M. Doğru, IZYEF, 71 (2012)

5. G. Karahan, PhD Thesis (ITU, Nuc. Ener. Ins., 1997)

6. H.L. Beck, II. USERDA Conf.-720805-P2, 101-104 (1982)

7. S. Şahin, Ph.D. Thesis (FU, Ins. of Sci. Tech., 2009)
8. H. Gür, F. Yıldırım Sönmez, M. Ay, Bitlis Province Environmental Status Report (2012)

9. LUDLUM Model 44-10 Gamma Scint. (Ludlum Meas.Inc., 2012)

10. S. Şahin, S. Niksarlıŏlu, M. Yılmaz, FUJS, 22 (2), 101-107 (2010)

11. UNSCEAR, Sources and effects of ionizing radiation. Report to General Assembly, with Scientific Annexes (United Nations, 1993) 